\title{
Deleterious FBXW7 Gene Mutation
}

National Cancer Institute

\section{Source}

National Cancer Institute. Deleterious FBXW7 Gene Mutation. NCI Thesaurus. Code C162041.

A change in the nucleotide sequence of the FBXW7 gene that is associated with increased risk of disease. 